\title{
T-Cell Costimulatory Blockade in Organ Transplantation
}

\author{
Jonathan S. Maltzman ${ }^{1}$ and Laurence A. Turka ${ }^{2}$ \\ ${ }^{1}$ Department of Medicine, Perelman School of Medicine at the University of Pennsylvania, \\ Philadelphia, Pennsylvania 19104 \\ ${ }^{2}$ Transplantation Biology Research Center, Department of Surgery, Massachusetts General Hospital \\ and Harvard Medical School, Boston, Massachusetts 02129 \\ Correspondence: Iturka@partners.org
}

Before it became possible to derive T-cell lines and clones, initial experimentation on the activation requirements of T lymphocytes was performed on transformed cell lines, such as Jurkat. These studies, although technically correct, proved misleading as most transformed T cells can be activated by stimulation of the clonotypic T-cell receptor (TCR) alone. In contrast, once it became possible to study nontransformed T cells, it quickly became clear that TCR stimulation by itself is insufficient for optimal activation of naïve T cells, but in fact, induces a state of anergy. It then became clear that functional activation of T cells requires not only recognition of major histocompatibility complex $(\mathrm{MHC})$ and peptide by the TCR, but also requires ligation of costimulatory receptors expressed on the cell surface.

Costimulatory molecules can be divided based on structural similarities, expression patterns, and functional outcome of stimulation. Costimulatory molecules are structurally categorized into immunoglobulin (Ig) superfamily, tumor necrosis factor receptor (TNFR) family, and the T-cell Ig and mucin (TIM) family. This review will focus on costimulatory receptor structure and signaling and review experimental, preclinical, and clinical data regarding their efficacy in transplantation.

\section{CD28/CTLA-4}

CD28 is both the first identified and the prototypical costimulatory receptor expressed by
T cells (June et al. 1987; Lindsten et al. 1989). Costimulation via CD28 is critical for activation of naïve Tlymphocytes and avoidance of anergy (Jenkins et al. 1987a,b; DeSilva et al. 1991; Harding et al. 1992). CD28 is expressed as a homodimer and binds the ligands CD80 (B7-1) and CD86 (B7-2) (June et al. 1994). In mice, CD28 is constitutively expressed by all $\mathrm{T}$ cells and by a small subset of myeloid-derived cells. In humans, CD28 is similarly restricted to T cells; all CD4 T cells constitutively express CD28, but expression is absent on a subset of CD8 memory T cells (Lenschow et al. 1996).

$\mathrm{CD} 28$ is a type I transmembrane receptor with a single immunoglobulin domain in the extracellular portion and a relatively short cy-

Editors: Laurence A. Turka and Kathryn J. Wood

Additional Perspectives on Transplantation available at www.perspectivesinmedicine.org

Copyright (C) 2013 Cold Spring Harbor Laboratory Press; all rights reserved; doi: 10.1101/cshperspect.a015537

Cite this article as Cold Spring Harb Perspect Med 2013;3:a015537 
toplasmic tail (Fig. 1). The cytoplasmic region ( 41 aa in human and 38 aa in mouse) has no intrinsic enzymatic activity, but contains several protein interaction motifs (Rudd and Schneider 2003). There are four tyrosines that can be phosphorylated, presumably by the src-family kinases LCK and FYN. When phosphorylated, these tyrosines can act as a binding site for proteins containing src-homology (SH)2 domains. There are also two PxxP motifs that mediate interactions with SH3 domains. Furthermore, there is a single YMNM motif allowing for interaction with the p85 subunit of PI3K as well as the Grb2/GADS adaptors. These initial phosphorylation and adaptor binding events lead to changes in downstream signal transduction and eventually changes in gene expression. Whether these proximal events mediate pathways distinct from the TCR or amplify TCR signals remains controversial. What is clear is that coligation of TCR/CD3 and CD28 leads directly to up-regulation of genes involved in T-cell activation including IL-2 and the IL-2 receptor $\alpha$ (CD25) genes. CD28 costimulation also results in transactivation of the antiapoptotic factors BCL2 and BCL-XL (Boise et al. 1995).

CTLA-4 also binds CD80/CD86 but differs in expression pattern, signaling, and functional outcome (Linsley et al. 1991; Krummel and Allison 1995). CTLA-4 is expressed as a homodimer on activated but not naïve $\mathrm{T}$ cells and constitutively on Foxp $3^{+}$regulatory $\mathrm{T}$ cells. There are multiple splice variants of CTLA-4 that have been correlated with susceptibility to autoimmune disease (Ueda et al. 2003). The extracellular portion of CTLA-4 is highly homologous to that of CD28 but has a higher binding affinity for CD80/CD86. The higher affinity has been exploited to generate a fusion protein (CTLA-4Ig) that interferes with CD28 activation and can alter in vivo immune responses (see below). The intracellular regions differ substantially resulting in alternate function. The CTLA-4 cytoplasmic tail contains a YxxM motif that binds PI3K but also the PP2A and SHP-2 phosphatases. Given the binding

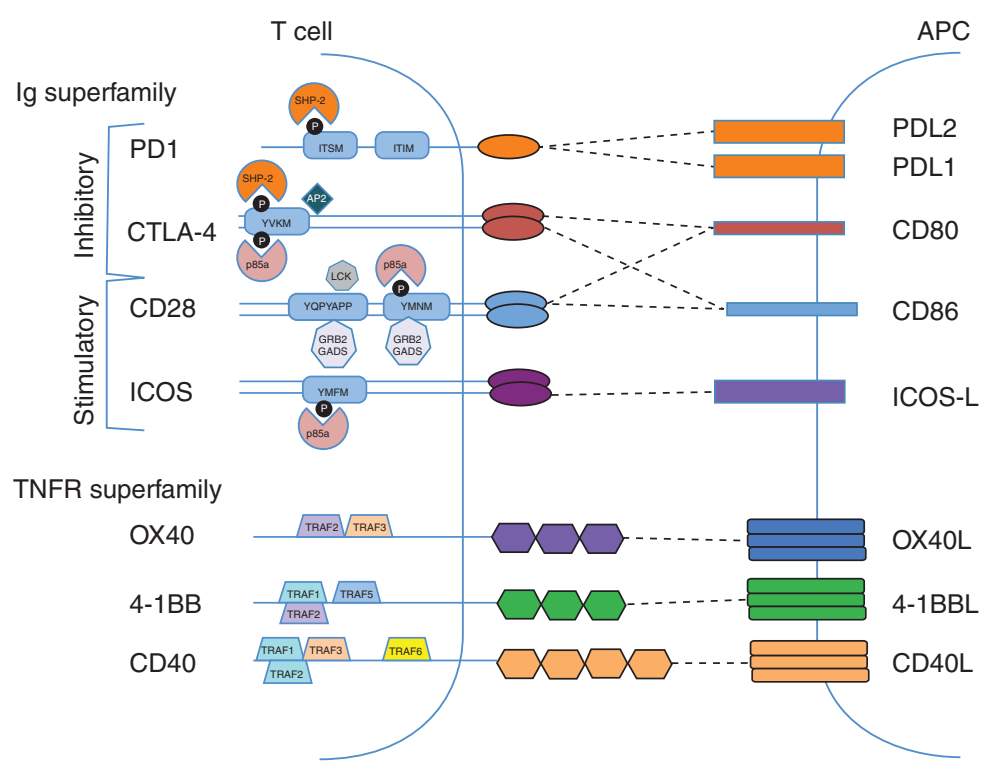

Figure 1. Costimulatory molecules and proximal signaling components. Immunoglobulin superfamily (top) and TNF superfamily receptors (bottom) expressed on T cells are shown on the left. Ligands are depicted in the antigen-presenting cell (APC) on the right. Dotted lines represent receptor-ligand pairs. Signaling motifs within the cytoplasmic tails are indicated in blue rectangles. Black circles represent phosphorylatable tyrosines. Proteins that interact directly with the cytoplasmic tails of costimulatory molecules are shown. Details of the signal transduction proteins are described in the text. 
of negative regulators, it is not surprising that CTLA-4 ligation sends a "negative" signal involving phosphatase-mediated inactivation of a number of proximal signaling pathways.

Until very recently, the major mechanism of CTLA-4-mediated function was believed to be cell intrinsic owing to increased affinity to CD80/CD86 and intracellular signal dampening, but there is a growing realization that CTLA-4 also functions in a cell-extrinsic manner (Walker and Sansom 2011; Corse and Allison 2012; Wang et al. 2012). Interestingly, a majority of CTLA-4 expressed in Tregs is localized to membranes of intracellular compartments rather than the cell surface (Leung et al. 1995; Valk et al. 2006). CTLA-4 is cycled to the surface of these cells following a TCR stimulation energy-dependent process likely involving TRIM (TCR interacting molecule) and the clatherin adaptor AP2 (Shiratori et al. 1997; Valk et al. 2006). Following binding of CTLA4 to B7 expressed on antigen-presenting cells, CTLA-4 internalizes and via continued interaction with CD80/CD86, removes those critical molecules from antigen-presenting cells through a process termed trans-endocytosis or trogocytosis (Qureshi et al. 2011). Thus, CTLA-4 can negatively regulate an immune response through cell intrinsic signal dampening and cell-extrinsic alteration of antigen-presenting cells.

Immunosuppressive agents to block the pathway by targeting the CD28 "positive" signal have been in development for more than two decades. Among the first approaches used, and one which turned out to be successful as well, was to use the extracellular portion of CTLA-4 to generate a fusion protein with the Fc portion of IgG1, called CTLA-4Ig (Linsley et al. 1992). Administration of CTLA-4Ig prolongs allograft and xenograft survival in rodent models of islet, heart, and kidney transplantation and can induce tolerance under some conditions (Lenschow et al. 1992; Turka et al. 1992; Lin et al. 1993; Pearson et al. 1994; Azuma et al. 1996). CTLA-4Ig has been used more effectively in combination with additional agents and is a cornerstone for most regimens of costimulation blockade in rodents (see below). Interestingly, depending on the details of the timing of ad- ministration and degree of mismatch, CTLA-4Ig administration can accelerate rejection, likely owing to the effects on regulatory T cells (Charbonnier et al. 2012; Riella et al. 2012).

\section{ICOS}

Inducible T-cell costimulator (ICOS; CD278) is an Ig superfamily member expressed as a disulfide-linked homodimer (Hutloff et al. 1999; Simpson et al. 2010). ICOS transcription is regulated by calcineurin-dependent signals downstream from TCR and CD28 (Tan et al. 2006). Original descriptions had expression limited to activated T lymphocytes, but ICOS has subsequently been detected on NK, NKT, and T regulatory cells.

ICOS activity is initiated by interaction with its ligand ICOSL (also known as B7RP-1, B7h, CD275) leading to increased survival and proliferation with reduced IL-2 production when compared with CD28 costimulation. The intracellular region of ICOS contains an SH2 binding YMFM motif that recruits both the p85 and p50 $\alpha$ regulatory isoforms of PI3K (Fos et al. 2008). The $\mathrm{p} 50 \alpha$ isoform imparts a stronger signal and greater downstream AKT activity when compared with CD28-mediated activation via p85. ICOS/ICOSL may be sufficient for AKT phosphorylation-independent TCR cross-linking (Fos et al. 2008). ICOS/ICOSL also activates the MAPK pathway with resulting phosphorylation of ERK and p38, but interestingly not JNK (Parry et al. 2003).

ICOS expression is critical for T-cell differentiation of Th1, Th2, and Th17 cells and their effector function (Gonzalo et al. 2001; Rottman et al. 2001; Banquet et al. 2009). There is conflicting data as to whether ICOS predominantly regulates Th1 versus Th2 responses. ICOS is critical for T-cell-dependent B-cell activation and function. ICOS-deficient mice display defective germinal center formation and immunoglobulin isotype switching (McAdam et al. 2001). These defects result from reduced $\mathrm{T}_{\mathrm{FH}}$ and Th17 generation and a reduction in CD40 L/CD154 expression on T cells (McAdam et al. 2001; Bauquet et al. 2009). Allograft survival of MHC-mismatched hearts is prolonged 
from $\sim 7$ to 21 days in both $\mathrm{ICOS}^{-/-}$recipient mice and in the setting of anti-ICOS antibody treatment (Ozkaynak et al. 2001). Interestingly, the combination of anti-ICOS plus cyclosporine was synergistic leading to $>100$ day survival without histological evidence of chronic rejection (Ozkaynak et al. 2001).

\section{PD1}

The programmed death 1 (PD1/CD279) receptor is a type 1 transmembrane protein with a single extracellular immunoglobulin domain that confers specificity to its ligands PDL1 and PDL2. PD1 is constitutively expressed on NK, NK-T, a subpopulation of dendritic cells (DCs), and activated monocytes. $\mathrm{PD} 1$ is not expressed on naïve $\mathrm{T}$ or B cells, but is up-regulated following activation, and is maintained by continuous TCR stimulation. High levels of PD1 are found on "exhausted" CD8 T cells during chronic infection (Barber et al. 2006). Transcription of PD1 is in part regulated by NFATc1; calcineurin inhibitor (CNI) treatment decreases PD1 levels (Oestreich et al. 2008). PD1 is expressed constitutively on Treg and TFH subsets of $\mathrm{CD} 4^{+} \mathrm{T}$ cells.

The intracellular region of PD1 contains immunoreceptor tyrosine-based inhibitory and switch motifs (ITIM and ITSM). Phosphorylation of these motifs leads to recruitment of SHP1 and SHP2 phosphatases. SHP1 and SHP2 dephosphorylate a number of key signaling molecules including CD3, ZAP70, and PI3K (Parry et al. 2005), thus inhibiting activating signals and costimulation. Signaling through $\mathrm{PD} 1$ can alter differentiation of $\mathrm{T}$ cells through decreasing GATA3, Tbet, and eomesodermin expression. PD1 ligation decreases TCR-mediated generation of effector cytokines such as IFN- $\gamma$, TNF- $\alpha$, and IL-2. Interestingly, blockade of PD1/PDL1 has been exploited to reverse T-cell exhaustion in mouse models of chronic infection and cancer (Iwai et al. 2002; Barber et al. 2006).

Experimental manipulation of the PD1/ PDL1 axis has shown that this inhibitory pathway is critical for allograft tolerance and rejection. In general, limiting PD1/PDL1 accelerates rejection. For example, PD1 KO or PDL1
KO recipients overcome costimulation blockade (CD154 + CTLA-4Ig)-induced tolerance and reject BALB/c vascularized heart allografts within 1-2 weeks (Wang et al. 2007). Conversely, blockade with a PDL1 fusion protein (PDL1Ig) in combination with cyclosporine or rapamycin significantly prolongs fully MHC-mismatched cardiac allograft survival (Ozkaynak et al. 2002).

\section{CD40/CD40L (CD154)}

CD40 and its ligand CD154 (CD40L/CD40 ligand) are costimulatory molecules critical for $\mathrm{B}-\mathrm{T}$ interactions required for generation of high affinity, isotype switched antibodies (Elgueta et al. 2009). CD40 is a type II transmembrane protein that is a member of the TNFR superfamily. The extracellular region contains a $\beta$-sheet, $\alpha$-helix loop, $\beta$-sheet sequence that allows for trimerization of the receptor. CD40 is expressed on antigen-presenting cells including dendritic cells, monocytes, and importantly on B lymphocytes. CD40 expression has also been shown on multiple nonhematopoietic cell types including fibroblasts, epithelial, and endothelial cells. CD154 is expressed primarily on activated $\mathrm{T}$ cells, but has been detected on activated B cells and platelets as well as monocytes, NK cells, mast cells, and basophils. Thrombosis as a result of CD154 expressed on platelets has limited its applicability as a therapeutic target (see below).

CD40 signaling depends on interaction of its cytoplasmic tail with TNFR-associated factors (TRAFs). There are six members of the TRAF family, designated TRAF1 through TRAF6. TRAF1, TRAF2, and TRAF 3 are recruited to CD40 via a PxQxT motif (Pullen et al. 1999); TRAF6 is recruited to the more membrane proximal QxPxEx sequence (Bishop et al. 2007). Activation of CD40 and recruitment of TRAFs leads to activation of the NF- $\kappa B$, p38, Jnk, and Akt pathways. The specific pathways regulated by different TRAF proteins is beyond the scope of this review and can be found in detail elsewhere (Elgueta et al. 2009).

CD40/CD40L interactions have roles in both T-cell- and B-cell-mediated immunity through direct effects on lymphocytes and via 
generation and stabilization of the germinal center response (Foy et al. 1993, 1994; Van den Eertwegh et al. 1993). CD40 expressing DCs and $\mathrm{B}$ cells can activate $\mathrm{T}$ cells in lymph nodes during a normal immune response generating germinal centers. CD40/CD40L interactions are critical for maturation and survival of DCs via activation of the NF- $\mathrm{B}$ pathway and up-regulation of the antiapoptotic factor Bcl-xL (Ouaaz et al. 2002). Survival and proliferation of B cells and activation of antigen-specific $\mathrm{T}$ cells also depend on CD40/CD40L interaction.

Interest in the CD40/CD40L pathway is second only to CD28/B7 in transplantation (reviewed in Quezada et al. 2004). A single dose of anti-CD40L (MR1 clone) is sufficient to induce long-term survival of fully mismatched cardiac allografts in a majority of mice (Hancock et al. 1996). Anti-CD40 treatment is synergistic with donor-specific transfusion (DST) of splenocytes resulting in long-term survival in 100\% of recipients (Hancock et al. 1996). Combining MR1 with CTLA-4Ig leads to long-term acceptance of heart or skin Balb/c to C3H allografts (Larsen et al. 1996). Conversely, CD40/ CD28 double knockout mice reject DBA/2 to C57BL/ 6 skin with only slightly delayed kinetics (Demirci et al. 2004).

\section{OX40}

OX40 (CD134; TNFRSF4) is a $50 \mathrm{kDa}$ type 1 transmembrane protein that is a member of the TNFR superfamily. OX40 is expressed on most CD4 and CD8 T lymphocytes including naïve, Th1, Th2, Th17, and Treg. It is not expressed on resting memory $\mathrm{T}$ cells but can be rapidly reexpressed following TCR stimulation. Expression on natural Tregs begins during development in the thymus and is constitutive. OX40 is also expressed by NK and NKT cells. OX40L, the only known ligand for OX40, is expressed as a trimer cell surface of APCs including B cells.

The OX40 cytoplasmic tail contains a single QEE motif that acts as a TRAF-binding site (Ye et al. 1999; Croft 2010). Ligation by OX40L leads trimerizes OX40 recruiting TRAF2, TRAF3, and TRAF5, which activate the canonical and noncannonical NF- $\kappa$ B pathways (Arch and Thompson 1998). NF-кB activity results in up-regulation of a number of prosurvival and proliferative factors such as AKT, Bcl-2, Bcl-xL, and surviving (Song et al. 2004, 2005).

OX40 functions to promote immune responses through increased survival and proliferation of effector $\mathrm{T}$ cells. $\mathrm{OX} 40^{-/-}$and OX40L $\mathrm{L}^{-/-}$mice have intact $\mathrm{CD}^{+}$but diminished $\mathrm{CD}^{+}{ }^{+}$effector responses to in vivo challenge (Chen et al. 1999; Kopf et al. 1999). The role of OX40 in Tregs has been more controversial. Genetic deletion of OX40 has no effect on Treg development or function (Vu et al. 2007). Conversely, ligation of OX40 and TCR on Tregs decreases Foxp3 transcription, per cell Foxp3 protein levels, and suppressive activity in vitro and in vivo (Vu et al. 2007).

Blockade of this pathway alone has little effect on allograft outcomes. In contrast, OX40/ OX40L interactions play a nonredundant role in the absence of CD28 and CD40. As mentioned above, CD $28^{-/-} \mathrm{CD} 40^{-/-}$mice reject DBA $/ 2$ skin. In these double knockouts or in the setting of CTLA-4Ig/anti-CD40L treatment, addition of OX40 blockade (but not anti-ICOS anti-41BB) induced long-term skin survival (Demirci et al. 2004).

\section{4-1BB}

4-1BB (CD137, tnfrsf9) is a transmembrane protein expressed on lymphocytes monocytes, dendritic cells, and B cells. Similar to many other costimulatory molecules discussed here, $4-1 \mathrm{BB}$ is not expressed on naïve T cells but rather on activated effector (Pollok et al. 1993; Dawicki and Watts 2004). The level of expression on Tregs is even higher and when combined with the absence of CD40L may allow for separation of human Foxp3 ${ }^{+}$Tregs from Foxp3 ${ }^{-}$ effectors (Schoenbrunn et al. 2012). The ligand for 4-1BB, 4-1BBL, is expressed on APCs including mature DCs, macrophages, and activated B cells (Pollok et al. 1994).

Similar to other TNF superfamily receptors, ligand binding leads to trimerization and recruitment of adaptors. In this case, it is TRAF1 and TRAF2 that transduce signals leading to activation of the NF- $\mathrm{B}$ and MAPK pathways. The cy- 
toplasmic tail of murine 4-1BB also has a $\mathrm{CxCP}$ sequence that mediates binding of the src-family kinase LCK (Kim et al. 1993). The relevance of the 4-1BB-LCK association remains unclear.

Depending on the experimental system, 41BB has been shown to have a role in $\mathrm{CD}^{+}$ and/or $\mathrm{CD}^{+}$T-cell responses. Specifically, 41BB-deficient mice have an intact CD4 response and impaired CD8 expansion and secondary responses in response to acute infection or vaccination (Tan et al. 1999, 2000). In contrast, the predominant effect of 4-1BBL deficiency in the setting of chronic infection is on the CD4 response (Fuse et al. 2007). 4-1BB-deficient mice reject allogeneic skin transplants with normal kinetics; mice deficient in both 4-1BB and CD28 show slightly delayed rejection (DeBenedette et al. 1999). Similarly, CD8 ${ }^{+}$T-cellmediated rejection of intestinal allografts is accelerated by treatment with $4-1 \mathrm{BB}$ agonistic antibody and delayed by $4-1 \mathrm{BB} / 4-1 \mathrm{BB}$ blockade (Wang et al. 2003). Furthermore, antibodymediated blockade leads to prolongation of fully MHC-mismatched heterotopic cardiac allografts and decreases allograft vasculopathy in a B6 into bm12 model (Cho et al. 2004; Saiki et al. 2008). Taken together, 4-1BB likely has a role in both CD4- and CD8-mediated aspects of transplant rejection.

\section{MOVING INTO THE CLINIC-FROM LARGE ANIMALS TO MAN}

\section{Nonhuman Primate Studies}

It is difficult to overestimate the excitement with which scientists and clinicians greeted the results from the initial mouse and rat studies of costimulatory blockade in transplantation. The findings that indefinite graft survival and tolerance could be induced by short-term administration of CTLA-4Ig and/or anti-CD154 mAb held the promise that tolerance might really be within reach, and led to the initiation of nonhuman primate studies of both agents.

\section{CTLA-4Ig}

The earliest reports using CTLA-4Ig in nonhuman primates were in islet allografts and re- nal allografts. In the islet allograft system, Levisetti et al. (1997) conducted a study in which five cynomologous monkeys were rendered diabetic with streptozotocin, transplanted with 12,000-20,000 islet equivalents, and treated with humanized CTLA-4Ig (hCTLA-4Ig) at a dose of $12.5 \mathrm{mg} / \mathrm{kg}$ daily on days $1-7$ followed by $12.5 \mathrm{mg}$ twice a day on days $8-14$. Although three of the five animals rapidly rejected their grafts (day 6), two of the five animals achieved prolonged graft survival, with insulin independence 30 days in one, and 50 days in another. Of note in this study, CTLA-4Ig prevented alloantibody formation in all monkeys, even those that rapidly rejected their grafts. Contemporaneous with that report, Kirk et al. (1997) performed renal allografts in rhesus monkeys. Two animals were treated with CTLA-4Ig. One received a dose of $10 \mathrm{mg} / \mathrm{kg}$ daily for 5 days and rejected its graft on day 20. The other was dosed every other day for 12 days and rejected its graft on day 30 .

\section{Anti-CD154}

Although these results with CTLA-4Ig were certainly disappointing, as noted above, studies in mice had revealed that antibodies to CD154 (at that time termed CD40L) were similarly effective as CTLA-4Ig for the induction of long-term graft survival, and that the two together had additive if not synergistic effects. Not surprisingly then, experiments using anti-CD154 mAb, either alone or in combination with CTLA-4Ig in nonhuman primates, were under way as well. It was first observed that a short course of anti-CD154 mAb alone was more effective than CTLA-4Ig alone and that the two together prolonged allograft survival up to 9 months, but did not lead to indefinite drug-free survival (Kirk et al. 1997, 1999).

Subsequently, Kirk and colleagues, rather than attempting to induce long-term graft survival with very short courses of one or both agents, treated animals with longer courses of drug, focusing on anti-CD154 as this seemed the more promising of the two. Using hu5C8, a humanized anti-CD154 mAb, they tested a clinically applicable protocol in which drug 
was given six times during the first 4 weeks, and at monthly intervals thereafter. Remarkably, eight of nine animals had long-term rejection-free survival, including periods exceeding 500 days. In five of these animals, drug had been discontinued for as long as a year. A second critical aspect of this study was that the addition of conventional immunosuppressive drugs (MMF, steroids, and/or tacrolimus) antagonized the salutary effects of anti-CD154, provoking rejection and graft loss. This finding paralleled similar results in mice, in which it was shown that a key mechanism by which costimulatory blockade worked in transplantation was through the deletion of alloreactive cells, and that calcineurin inhibitors prevented tolerance induction by blocking deletion (Li et al. 1999; Wells et al. 1999).

Other notable findings of Kirk et al. were that anti-CD154 did not act by global T-cell depletion and did not prevent donor-specific antibody formation. In retrospect, this latter point is interesting in light of accumulating reports of tolerant renal and liver transplant recipients who have donor-specific antibody but excellent stable graft function.

\section{Into Man with Anti-CD40L}

Unfortunately, efforts to translate anti-CD154 into humans revealed unacceptable toxicity of the drug. This manifested as elevated incidences of thromboembolic events in early clinical trials of two anti-CD154 mAbs, hu5c8, and toralizumab (IDEC 131). It was subsequently shown that activated platelets express CD154 (Henn et al. 1998) and that hu5C8 induced platelet expression of adhesion molecules and chemokines, providing a mechanistic explanation for the side effects observed in humans, and demonstrating that this was actually an "on-target" effect.

\section{Back to CTLA-4Ig}

In the wake of the problems with anti-CD154, the community refocused its interests on CTLA-4Ig, with the notion that rather than being used to induce tolerance, perhaps CTLA-4Ig could be used as part of an improved (either because of enhanced efficacy or reduced toxicity) immunosuppressive regimen. Consistent with this, a phase I study of CTLA-4Ig in 43 patients with psoriasis showed that the drug was safe, and compared with historical controls, induced improvement in disease activity, although this effect was transient and reverted after the drug was discontinued (Abrams et al. 1999). Building on this experience, CTLA-4Ig was developed for use in rheumatoid arthritis (Kremer et al. 2003), and is currently an approved drug for this indication under the generic name abatacept.

The relatively disappointing results with CTLA-4Ig in nonhuman primate transplantation studies led to a reevaluation of its binding interactions. These experiments revealed that although CTLA-4Ig does have a higher affinity for CD80 and CD86 than did CD28, it is markedly less effective in blocking CD86-mediated costimulation than CD80, perhaps because of a relatively lower avidity for CD86 (Larsen et al. 2005). By performing mutagenesis and screening, a higher avidity "version" of CTLA-4Ig with two amino acid substitutions was created, and was termed LEA29Y or belatacept (Larsen et al. 2005). The first set of studies of belatacept showed a synergistic effect with the anti-CD25 $\mathrm{mAb}$ basiliximab, with five of six recipients having stable creatinines for $>100$ days, and no rejection episodes occurring during the period of belatacept administration (which was given biweekly through day 70). These encouraging results paved the way for the development of belatacept for renal transplantation. As will be discussed in detail in another article of this monograph, belatacept gained FDA approval via registration trials designed to show its noninferiority to calcineurin ihibitors.

As noted above, in murine systems costimulatory blockade is able to induce transplant tolerance via deletion of alloreactive cells. Concomitant with this, and perhaps owing to the suppression of inflammation and an effector immune response, Foxp $3^{+}$regulatory $\mathrm{T}$ cells accumulate (owing to expansion of preexisting nTregs and/or induction of adaptive Tregs). Moreover, Tregs are required for maintenance 
of tolerance in mice. In humans, costimulatory blockade does not induce tolerance per se, but there is evidence to suggest that it may promote Tregs. This may appear surprising, as data from murine systems shows that Tregs require CD28 for development and maintenance (Zhang et al. 2013), and that CTLA-4Ig may cause a loss of Tregs from blood and lymphoid tissues (Salomon et al. 2000; Bour-Jordan and Bluestone 2009; Yang et al. 2009). Nonetheless, Bluestone et al. (2008) in a series of $8-10$ patients, have reported that a basiliximab/belatacept regimen does not have a long-term effect on circulating Foxp $3^{+}$Tregs, perhaps because CD86 is not fully saturated at these doses, and thus allows for CD28 costimulation. Furthermore, in one small series of patients, a belatacept regimen that did not contain anti-CD25 therapy also augmented Treg percentages in the peripheral blood of transplant recipients (Bestard et al. 2011).

Additional insight may be gained by findings in a related clinical setting, bone marrow transplantation. Beginning more than a decade ago, Guinan and colleagues performed a series of clinical studies in which patients undergoing MHC-mismatched myeloablative bone marrow transplants for hematologic malignancies received donor bone marrow that had been "anergized" against recipient alloantigens by brief culture with irradiated recipient APCs plus CTLA-4Ig before infusion. These studies (Guinan et al. 1999) revealed that the procedure was safe and did not result in either engraftment failure or increased susceptibility to infections. Moreover, graft versus host disease was less than what would have been predicted based on historical controls. Most importantly, they found that in vitro culture with CTLA-4Ig promoted the accumulation of donor-specific Foxp $3^{+}$ Tregs, while not affecting responses to thirdparty antigens or pathogens (Davies et al. 2008, 2009).

Based on this data, this group is currently initiating studies to exploit this approach in solid organ transplantation. Here, using onehaplotype mismatched live-donor renal transplants, the plan is to produce/expand recipient antidonor antigen-specific Tregs by culture of unfractionated recipient $\mathrm{T}$ cells with irradi- ated donor APCs plus belatacept, followed by magnetic bead separation of Tregs (identified as $\left.\mathrm{CD} 25^{\mathrm{hi}} \mathrm{CD} 127^{\mathrm{lo}}\right)$. These cells could then be used for infusion posttransplantation. Particularly attractive is a clinical protocol involving induction thymoglobulin and maintenance rapamycin, as this would "create space" and use an immunosuppressive milieu that would promote the expansion of cells postinfusion once the thymoglobulin is cleared.

\section{What's Next?}

\section{Selective CD28 Blockade}

Although still unproven, in theory, agents that bind to B7 molecules may have undesired counteracting effects by preventing them from engaging negative signaling molecules on $\mathrm{T}$ cells such as CTLA-4 and PD-1. Although this concern remains hypothetical, in part because of the continued uncertainty regarding the mechanism of action of CTLA-4 and whether or not negative signaling is part of how it functions to inhibit immune responses, it has nonetheless been the impetus to develop agents that would selectively bind to and block CD28 itself, rather than its ligands.

Most anti-CD28 Abs are stimulatory, but a few monovalent fusion antibodies have been developed that, most likely because they are incapable of cross-linking CD28, are blocking and inhibitory. These were initially used successfully in mouse and rat transplant experiments, and more recently have been applied to nonhuman primate renal and cardiac transplantation (Poirier et al. 2010). In this setting, long-term survival of both renal and cardiac allografts was achieved by the combination of a selective antiCD28 inhibitor in combination with either tacrolimus or cyclosporine. Notably, this regimen also inhibited alloantibody production and cardiac allograft vasculopathy.

Further studies in primates and mice suggest that Tregs and negative signaling via CTLA4 may be an important component of long-term engraftment (Poirier et al. 2010; Zhang et al. 2011). It cannot necessarily be concluded, however, that these features are owing to "sparing" of a B7:CTLA-4 interaction, as long-term engraft- 
ment induced by a brief course of CTLA-4Ig similarly depends on Tregs and CTLA-4 (Tran et al. 1997). More likely is the fact that the establishment of an allograft in a noninflammatory environment promotes the development of regulatory $\mathrm{T}$ cells. However, the synergy of CD28-blockade with calcineurin inhibitors (CNIs) is particularly noteworthy because, as discussed above, CNIs antagonize the effects of anti-CD154 in nonhuman primate transplantation (Kirk et al. 1997, 1999).

Agents that selectively block CD28 may still have the theoretical drawback of blocking regulatory T-cell pathways because, as noted above, CD28 is needed for optimal development and survival of Tregs. However, very early clinical data suggests that belatacept as currently dosed may not block the maintenance or expansion of Tregs, and thus it is possible that a CD28-specific inhibitor might be developed that would show the same pharmacodynamic feature. Perhaps the biggest barrier to the application of selective anti-CD28 mAbs in human transplant trials is the catastrophic immune activation that occurred in the trial of the superagonist antiCD28 Ab TGN1412 (Suntharalingam et al. 2006). Although there is no evidence that antiCD28 blocking agents would have a similar effect, caution is likely to be the byword in this area, and extensive preclinical testing that takes into account species-specific differences in the types of T cells that express CD28 will be required (Eastwood et al. 2010; Hunig 2012).

\section{Activating Inhibition}

With the discovery that $\mathrm{T}$ cells express "coinhibitory" as well as costimulatory receptors, agents that were capable of activating these negative-regulatory pathways became an obvious approach to blocking immune responses. The best such candidate molecules to target at present would appear to be CTLA-4 and PD-1. Unfortunately, application of this concept is hindered by the absence of reagents that "turnon" these inhibitory pathways; all reagents available at present are blocking antibodies, which thus lead to immunoenhancement. Nonetheless, recent studies showing that blockade of
CTLA-4 or PD-1 can be a therapeutically useful maneuver in cancer immunotherapy (Hodi et al. 2010; Topalian et al. 2012) provide evidence for the importance of these pathways in humans and support the notion that activating negativeregulatory molecules might be an effective way to turn off pathogenic immune responses.

\section{CD154:CD40}

Despite the problems noted above associated with the anti-CD154 mAb hu5c8, interest in blocking this pathway has continued owing to its impressive efficacy in preclinical studies. One idea has been to develop anti-CD154-targeted agents that will not induce thromboembolic events. A number of companies are currently working on this area, although preclinical data are not yet available. An alternative approach is to block CD40, and a number of such Abs have been studied in nonhuman primate models. The anti-CD40 mAb 4D11 can induce relatively long-term renal allograft survival in cynomolgus monkeys, although animals eventually rejected even when given continued maintenance treatment (Aoyagi et al. 2009). Another anti-CD40 $\mathrm{mAb}, 3 \mathrm{~A} 8$, was shown to be effective in rhesus islet transplantation, and the combination of $3 \mathrm{~A} 8$ and anti-CD25 mAb plus sirolimus induced long-term survival (Badell et al. 2012). Similar results were seen with the anti-CD40 mAb 2C10 (Lowe et al. 2012). Notably, in each of the antiCD40 studies, no thromboembolic complications were observed. Based on the promise of these studies, it seems likely that we will see clinical development of one or more of these agents.

\section{LFA-3 (CD58)}

The precise role of the CD58-CD2 interaction in human T-cell activation remains poorly understood. In part this stems from the fact that in mice, CD48, rather than CD58, is the CD2 ligand. Nonetheless, ample evidence for the importance of this pathway in humans led to the development of alefacept, an LFA-3/Fc fusion protein that would bind to, and block, CD2. Alefacept is currently FDA approved for the treatment of psoriasis and until 2011 was marketed by Astellas under the trade name Amevive. 
Astellas has recently decided to discontinue marketing of the drug for business reasons, and thus the future of agents that target CD58 are uncertain. This is unfortunate, as alefacept was recently shown to selectively target memory $\mathrm{T}$ cells and, in combination with CTLA-4Ig plus sirolimus, lead to long-term renal allograft survival in rhesus macaques (Weaver et al. 2009).

\section{CONCLUSIONS}

More than two decades ago, it seemed to many that blocking T-cell costimulation held the promise to achieve transplantation tolerance. Although that has yet to come to fruition, the concept of costimulatory blockade has been translated into clinical practice in both autoimmunity and transplantation. For the near to medium term future, it is likely the use of these agents will be in the context of strategies to minimize immunosuppression and immunosuppressive side effects, with tolerance studies being appropriately restricted to carefully monitored clinical trials.

\section{REFERENCES}

Abrams JR, Lebwohl MG, Guzzo CA, Jegasothy BV, Goldfarb MT, Goffe BS, Menter A, Lowe NJ, Krueger G, Brown MJ, et al. 1999. CTLA4Ig-mediated blockade of T-cell costimulation in patients with psoriasis vulgaris. J Clin Invest 103: 1243-1252.

Aoyagi T, Yamashita K, Suzuki T, Uno M, Goto R, Taniguchi M, Shimamura T, Takahashi N, Miura T, Okimura K, et al. 2009. A human anti-CD40 monoclonal antibody, 4D11, for kidney transplantation in cynomolgus monkeys: Induction and maintenance therapy. Am J Transplant 9: $1732-1741$.

Arch RH, Thompson CB. 1998. 4-1BB and Ox40 are members of a tumor necrosis factor (TNF)-nerve growth factor receptor subfamily that bind TNF receptor-associated factors and activate nuclear factor кB. Mol Cell Biol 18: 558-565.

Azuma H, Chandraker A, Nadeau K, Hancock WW, Carpenter CB, Tilney NL, Sayegh MH. 1996. Blockade of Tcell costimulation prevents development of experimental chronic renal allograft rejection. Proc Natl Acad Sci 93: 12439-12444.

Badell IR, Thompson PW, Turner AP, Russell MC, Avila JG, Cano JA, Robertson JM, Leopardi FV, Strobert EA, Iwakoshi NN, et al. 2012. Nondepleting anti-CD40-based therapy prolongs allograft survival in nonhuman primates. Am J Transplant 12: 126-135.
Barber DL, Wherry EJ, Masopust D, Zhu B, Allison JP, Sharpe AH, Freeman GJ, Ahmed R. 2006. Restoring function in exhausted CD8 T cells during chronic viral infection. Nature 439: 682-687.

Bauquet AT, Jin H, Paterson AM, Mitsdoerffer M, Ho IC, Sharpe AH, Kuchroo VK. 2009. The costimulatory molecule ICOS regulates the expression of c-Maf and IL-21 in the development of follicular T helper cells and TH-17 cells. Nat Immunol 10: 167-175.

Bestard O, Cassis L, Cruzado JM, Torras J, Franquesa M, Gil-Vernet S, Lucia M, Grinyó JM. 2011. Costimulatory blockade with mTor inhibition abrogates effector T-cell responses allowing regulatory $\mathrm{T}$-cell survival in renal transplantation. Transpl Int 24: 451-460.

Bishop GA, Moore CR, Xie P, Stunz LL, Kraus ZJ. 2007. TRAF proteins in CD40 signaling. Adv Exp Med Biol 597: $131-151$.

Bluestone JA, Liu W, Yabu JM, Laszik ZG, Putnam A, Belingheri M, Gross DM, Townsend RM, Vincenti F. 2008. The effect of costimulatory and interleukin 2 receptor blockade on regulatory $\mathrm{T}$ cells in renal transplantation. Am J Transplant 8: 2086-2096.

Boise LH, Minn AJ, Noel PJ, June CH, Accavitti MA, Lindsten T, Thompson CB. 1995. CD28 costimulation can promote $\mathrm{T}$ cell survival by enhancing the expression of Bcl-xL. Immunity 3: 87-98.

Bour-Jordan H, Bluestone JA. 2009. Regulating the regulators: Costimulatory signals control the homeostasis and function of regulatory T cells. Immunol Rev 229: 41-66.

Charbonnier LM, Vokaer B, Lemaître PH, Field KA, Leo O, Le Moine A. 2012. CTLA4-Ig restores rejection of MHC class-II mismatched allografts by disabling IL-2-expanded regulatory T cells. Am J Transplant 12: 2313-2321.

Chen AI, McAdam AJ, Buhlmann JE, Scott S, Lupher ML Jr, Greenfield EA, Baum PR, Fanslow WC, Calderhead DM, Freeman GJ, et al. 1999. Ox40-ligand has a critical costimulatory role in dendritic cell: $\mathrm{T}$ cell interactions. Immunity 11: 689-698.

Cho HR, Kwon B, Yagita H, La S, Lee EA, Kim JE, Akiba H, Kim J, Suh JH, Vinay DS, et al. 2004. Blockade of 4-1BB (CD137)/4-1BB ligand interactions increases allograft survival. Transpl Int 17: 351-361.

Corse E, Allison JP. 2012. Cutting edge: CTLA-4 on effector $\mathrm{T}$ cells inhibits in trans. J Immunol 189: 1123-1127.

Croft M. 2010. Control of immunity by the TNFR-related molecule OX40 (CD134). Annu Rev Immunol 28: 57-78.

Davies JK, Gribben JG, Brennan LL, Yuk D, Nadler LM, Guinan EC. 2008. Outcome of alloanergized haploidentical bone marrow transplantation after ex vivo costimulatory blockade: Results of 2 phase 1 studies. Blood 112: 2232-2241.

Davies JK, Nadler LM, Guinan EC. 2009. Expansion of allospecific regulatory $\mathrm{T}$ cells after anergized, mismatched bone marrow transplantation. Sci Transl Med 1: p1ra3.

Dawicki W, Watts TH. 2004. Expression and function of 4-1BB during CD4 versus CD8 T cell responses in vivo. Eur J Immunol 34: 743-751.

DeBenedette MA, Wen T, Bachmann MF, Ohashi PS, Barber BH, Stocking KL, Peschon JJ, Watts TH. 1999. Analysis of 4-1BB ligand (4-1BBL)-deficient mice and of mice lacking both $4-1 \mathrm{BBL}$ and $\mathrm{CD} 28$ reveals a role for $4-1 \mathrm{BBL}$ in 
skin allograft rejection and in the cytotoxic $\mathrm{T}$ cell response to influenza virus. J Immunol 163: 4833-4841.

Demirci G, Amanullah F, Kewalaramani R, Yagita H, Strom TB, Sayegh MH, Li XC. 2004. Critical role of OX40 in CD28 and CD154-independent rejection. J Immunol 172: $1691-1698$.

DeSilva DR, Urdahl KB, Jenkins MK. 1991. Clonal anergy is induced in vitro by $\mathrm{T}$ cell receptor occupancy in the absence of proliferation. J Immunol 147: 3261-3267.

Eastwood D, Findlay L, Poole S, Bird C, Wadhwa M, Moore M, Burns C, Thorpe R, Stebbings R. 2010. Monoclonal antibody TGN1412 trial failure explained by species differences in CD28 expression on CD4 ${ }^{+}$effector memory T-cells. Br J Pharmacol 161: 512-526.

Elgueta R, Benson MJ, de Vries VC, Wasiuk A, Guo Y, Noelle RJ. 2009. Molecular mechanism and function of CD40/ CD40 L engagement in the immune system. Immunol Rev 229: $152-172$.

Fos C, Salles A, Lang V, Carrette F, Audebert S, Pastor S, Ghiotto M, Olive D, Bismuth G, Nunès JA. 2008. ICOS ligation recruits the pp50 $\alpha$ PI3K regulatory subunit to the immunological synapse. J Immunol 181: 1969-1977.

Foy TM, Shepherd DM, Durie FH, Aruffo A, Ledbetter JA, Noelle RJ. 1993. In vivo CD40-gp39 interactions are essential for thymus-dependent humoral immunity. II: Prolonged suppression of the humoral immune response by an antibody to the ligand for CD40, gp39. J Exp Med 178: $1567-1575$.

Foy TM, Laman JD, Ledbetter JA, Aruffo A, Claassen E, Noelle RJ. 1994. gp39-CD40 interactions are essential for germinal center formation and the development of B cell memory. J Exp Med 180: 157-163.

Fuse S, Bellfy S, Yagita H, Usherwood EJ. 2007. CD8 ${ }^{+}$T cell dysfunction and increase in murine gammaherpesvirus latent viral burden in the absence of 4-1BB ligand. J Immunol 178: 5227-5236.

Gonzalo JA, Tian J, Delaney T, Corcoran J, Rottman JB, Lora J, Al-garawi A, Kroczek R, Gutierrez-Ramos JC, Coyle AJ. 2001. ICOS is critical for T helper cell-mediated lung mucosal inflammatory responses. Nat Immunol 2: 597604.

Guinan EC, Boussiotis VA, Neuberg D, Brennan LL, Hirano N, Nadler LM, Gribben JG. 1999. Transplantation of anergic histoincompatible bone marrow allografts. $N$ Engl J Med 340: 1704-1714.

Hancock WW, Sayegh MH, Zheng XG, Peach R, Linsley PS, Turka LA. 1996. Costimulatory function and expression of CD40 ligand, CD80, and CD86 in vascularized murine cardiac allograft rejection. Proc Natl Acad Sci 93: 1396713972.

Harding FA, McArthur JG, Gross JA, Raulet DH, Allison JP. 1992. CD28-mediated signalling co-stimulates murine $\mathrm{T}$ cells and prevents induction of anergy in T-cell clones. Nature 356: 607-609.

Henn V, Slupsky JR, Gräfe M, Anagnostopoulos I, Förster R, Müller-Berghaus G, Kroczek RA. 1998. CD40 ligand on activated platelets triggers an inflammatory reaction of endothelial cells. Nature 391: 591-594.

Hodi FS, O'Day SJ, McDermott DF, Weber RW, Sosman JA, Haanen JB, Gonzalez R, Robert C, Schadendorf D, Hassel JC, et al. 2010. Improved survival with ipilimumab in patients with metastatic melanoma. $N$ Engl J Med 363: 711-723.

Hunig T. 2012. The storm has cleared: Lessons from the CD28 superagonist TGN1412 trial. Nat Rev Immunol 12: $317-318$.

Hutloff A, Dittrich AM, Beier KC, Eljaschewitsch B, Kraft R, Anagnostopoulos I, Kroczek RA. 1999. ICOS is an inducible T-cell co-stimulator structurally and functionally related to CD28. Nature 397: 263-266.

Iwai Y, Ishida M, Tanaka Y, Okazaki T, Honjo T, Minato N. 2002. Involvement of PD-L1 on tumor cells in the escape from host immune system and tumor immunotherapy by PD-L1 blockade. Proc Natl Acad Sci 99: 12293-12297.

Jenkins MK, Pardoll DM, Mizuguchi J, Chused TM, Schwartz RH. 1987a. Molecular events in the induction of a nonresponsive state in interleukin 2-producing helper T-lymphocyte clones. Proc Natl Acad Sci 84: 5409.

Jenkins MK, Ashwell JD, Schwartz RH. 1987b. Allogeneic non-T spleen cells restore the responsiveness of normal $\mathrm{T}$ cell clones stimulated with antigen and chemically modified antigen-presenting cells. J Immunol 140: 33243330.

June CH, Ledbetter JA, Gillespie MM, Lindsten T, Thompson CB. 1987. T cell proliferation involving the CD28 pathway is associated with cyclosporine-resistant interleukin 2 gene expression. Mol Cell Biol 7: 4472-4481.

June CH, Bluestone JA, Nadler LM, Thompson CB. 1994. The B7 and CD28 receptor families. Immunol Today 15: 321-331.

Kim YJ, Pollok KE, Zhou Z, Shaw A, Bohlen JB, Fraser M, Kwon BS. 1993. Novel T cell antigen 4-1BB associates with the protein tyrosine kinase pp56lck1. J Immunol 151: $1255-1262$.

Kirk AD, Harlan DM, Armstrong NN, Davis TA, Dong Y, Gray GS, Hong X, Thomas D, Fechner JH Jr, Knechtle SJ. 1997. CTLA4-Ig and anti-CD40 ligand prevent renal allograft rejection in primates. Proc Natl Acad Sci 94: 87898794.

Kirk AD, Burkly LC, Batty DS, Baumgartner RE, Berning JD, Buchanan K, Fechner JH Jr, Germond RL, Kampen RL, Patterson NB, et al. 1999. Treatment with humanized monoclonal antibody against CD154 prevents acute renal allograft rejection in nonhuman primates. Nat Med 5: 686-693.

Kopf M, Ruedl C, Schmitz N, Gallimore A, Lefrang K, Ecabert B, Odermatt B, Bachmann MF. 1999. OX40-deficient mice are defective in Th cell proliferation but are competent in generating B cell and CTL Responses after virus infection. Immunity 11: 699-708.

Kremer JM, Westhovens R, Leon M, Di Giorgio E, Alten R, Steinfeld S, Russell A, Dougados M, Emery P, Nuamah IF, et al. 2003. Treatment of rheumatoid arthritis by selective inhibition of T-cell activation with fusion protein CTLA4Ig. N Engl J Med 349: 1907-1915.

Krummel MF, Allison JP. 1995. CD28 and CTLA-4 have opposing effects on the response of T cells to stimulation. $J$ Exp Med 182: 459-465.

Larsen CP, Elwood ET, Alexander DZ, Ritchie SC, Hendrix R, Tucker-Burden C, Cho HR, Aruffo A, Hollenbaugh D, Linsley PS, et al. 1996. Long-term acceptance of skin and cardiac allografts after blocking CD40 and CD28 pathways. Nature 381: 434-438. 
Larsen CP, Pearson TC, Adams AB, Tso P, Shirasugi N, Strobert E, Anderson D, Cowan S, Price K, Naemura J, et al. 2005. Rational development of LEA29Y, a high affinity variant of CTLA4Ig with potent immunosuppressive properties. Am J Transpl 5: 443-453.

Lenschow DJ, Zeng Y, Thistlethwaite JR, Montag A, Brady W, Gibson MG, Linsley PS, Bluestone JA. 1992. Longterm survival of xenogeneic pancreatic islet grafts induced by CTLA4Ig. Science 257: 789-792.

Lenschow DJ, Walunas TL, Bluestone JA. 1996. CD28/B7 system of T cell costimulation. Ann Rev Immunol 14: 233-258.

Leung HT, Bradshaw J, Cleaveland JS, Linsley PS. 1995. Cytotoxic T lymphocyte-associated molecule-4, a highavidity receptor for CD80 and CD86, contains an intracellular localization motif in its cytoplasmic tail. J Biol Chem 270: 25107-25114.

Levisetti MG, Padrid PA, Szot GLMittal N, Meehan M, Wardrip CL, Gray GS, Bruce DS, Thistlethwaite JR, Bluestone JA. 1997. Immunosuppressive effects of human CTLA4Ig in a non-human primate model of allogeneic pancreatic islet transplantation. J Immunol 159: 5187-5191.

Li Y, Li XC, Wells AD, Zheng XX, Turka LA, Strom TB. 1999. Blocking both signal 1 and signal 2 of $\mathrm{T}$ cell activation prevents apoptosis of alloreactive $\mathrm{T}$ cells and induction of peripheral allograft tolerance. Nat Med 5: 1298-1302.

Lin H, Bolling SF, Linsley PS, Wei RQ, Gordon D, Thompson CB, Turka LA. 1993. Long-term acceptance of major histocompatibility complex mismatched cardiac allografts induced by CTLA4Ig plus donor-specific transfusion. J Exp Med 178: 1801-1806.

Lindsten T, June CH, Ledbetter JA, Stella G, Thompson CB. 1989. Regulation of lyphokine messenger RNA stability by surface-mediated T cell activation pathway. Science 244: 339.

Linsley PS, Brady W, Urnes M, Grosmaire LS, Damle NK, Ledbetter JA. 1991. CTLA-4 is a second receptor for the $B$ cell activation antigen B7. J Exp Med 174: 561-569.

Linsley PS, Wallace PM, Johnson J, Gibson MG, Greene JL, Ledbetter JA, Singh C, Tepper MA. 1992. Immunosuppression in vivo by a soluble form of the CTLA-4 T cell activation molecule. Science 257: 792-795.

Lowe M, Badell IR, Thompson P, Martin B, Leopardi F, Strobert E, Price AA, Abdulkerim HS, Wang R, Iwakoshi NN, et al. 2012. A novel monoclonal antibody to CD40 prolongs islet allograft survival. Am J Transplant 12: 2079-2087.

McAdam AJ, Greenwald RJ, Levin MA, Chernova T, Malenkovich N, Ling V, Freeman GJ, Sharpe AH. 2001. ICOS is critical for CD40-mediated antibody class switching. Nature 409: 102-105.

Oestreich KJ, Yoon H, Ahmed R, Boss JM. 2008. NFATc1 regulates PD-1 expression upon T cell activation. J Immunol 181: 4832-4839.

Ouaaz F, Arron J, Zheng Y, Choi Y, Beg AA. 2002. Dendritic cell development and survival require distinct NF- $\kappa B$ subunits. Immunity 16: 257-270.

Ozkaynak E, Gao W, Shemmeri N, Wang C, Gutierrez-Ramos JC, Amaral J, Qin S, Rottman JB, Coyle AJ, Hancock WW. 2001. Importance of ICOS-B7RP-1 costimulation in acute and chronic allograft rejection. Nat Immunol 2: 591-596.
Ozkaynak E, Wang L, Goodearl A, McDonald K, Qin S, O'Keefe T, Duong T, Smith T, Gutierrez-Ramos JC, Rottman JB, et al. 2002. Programmed death-1 targeting can promote allograft survival. J Immunol 169: 6546-6553.

Parry RV, Rumbley CA, Vandenberghe LH, June CH, Riley JL. 2003. CD28 and inducible costimulatory protein Src homology 2 binding domains show distinct regulation of phosphatidylinositol 3-kinase, Bcl-xL, and IL-2 expression in primary human CD4 T lymphocytes. J Immunol 171: $166-174$

Parry RV, Chemnitz JM, Frauwirth KA, Lanfranco AR, Braunstein I, Kobayashi SV, Linsley PS, Thompson CB, Riley JL. 2005. CTLA-4 and PD-1 receptors inhibit T-cell activation by distinct mechanisms. Mol Cell Biol 25: 9543-9553.

Pearson TC, Alexander DZ, Winn KJ, Linsley PS, Lowry RP, Larsen CP. 1994. Transplantation tolerance induced by CTLA4-Ig. Transplantation 57: 1701-1706.

Poirier N, Azimzadeh AM, Zhang T, Dilek N, Mary C, Nguyen B, Tillou X, Wu G, Reneaudin K, Hervouet J, et al. 2010. Inducing CTLA-4-dependent immune regulation by selective CD28 blockade promotes regulatory T cells in organ transplantation. Sci Transl Med 2: 17ra10.

Pollok KE, Kim YJ, Zhou Z, Hurtado J, Kim KK, Pickard RT, Kwon BS. 1993. Inducible T cell antigen 4-1BB. Analysis of expression and function. J Immunol 150: 771-781.

Pollok KE, Kim YJ, Hurtado J, Zhou Z, Kim KK, Kwon BS, 1994. 4-1BB T-cell antigen binds to mature B cells and macrophages, and costimulates anti- $\mu$-primed splenic B cells. Eur J Immunol 24: 367-374.

Pullen SS, Labadia ME, Ingraham RH, McWhirter SM, Everdeen DS, Alber T, Crute JJ, Kehry MR. 1999. Highaffinity interactions of tumor necrosis factor receptorassociated factors (TRAFs) and CD40 require TRAF trimerization and CD40 multimerization. Biochemistry 38: $10168-10177$.

Quezada SA, Jarvinen LZ, Lind EF, Noelle RJ. 2004. CD40 CD154 interactions at the interface of tolerance and immunity. Annu Rev Immunol 22: 307-328.

Qureshi OS, Zheng Y, Nakamura K, Attridge K, Manzotti C, Schmidt EM, Baker J, Jeffery LE, Kaur S, Briggs Z, et al. 2011. Trans-endocytosis of CD80 and CD86: A molecular basis for the cell-extrinsic function of CTLA-4. Science 332: $600-603$.

Riella LV, Liu T, Yang J, Chock S, Shimizu T, Mfarrej B, Batal I, Xiao X, Sayegh MH, Chandraker A. 2012. Deleterious effect of CTLA4-Ig on a Treg-dependent transplant model. Am J Transplant 12: 846-855.

Rottman JB, Smith T, Tonra JR, Ganley K, Bloom T, Silva R, Pierce B, Gutierrez-Ramos JC, Ozkaynak E, Coyle AJ. 2001. The costimulatory molecule ICOS plays an important role in the immunopathogenesis of EAE. Nat Immunol 2: 605-611.

Rudd CE, Schneider H. 2003. Unifying concepts in CD28, ICOS and CTLA4 co-receptor signalling. Nat Rev Immunol 3: 544-556.

Saiki H, Suzuki J, Kosuge H, Haraguchi G, Ishihara T, Haga T, Maejima Y, Isobe M, Uede T. 2008. Blockade of the 4$1 \mathrm{BB}$ pathway attenuates graft arterial disease in cardiac allografts. Int Heart J 49: 105-118.

Salomon B, Lenschow DJ, Rhee L, Ashourian N, Singh B, Sharpe A, Bluestone JA. 2000. B7/CD28 costimulation is 
essential for the homeostasis of the $\mathrm{CD} 4^{+} \mathrm{CD} 25^{+}$immunoregulatory $\mathrm{T}$ cells that control autoimmune diabetes. Immunity 12: 431-440.

Schoenbrunn A, Frentsch M, Kohler S, Keye J, Dooms H, Moewes B, Dong J, Loddenkemper C, Sieper J, Wu P, et al. 2012. A converse 4-1BB and CD40 ligand expression pattern delineates activated regulatory $\mathrm{T}$ cells (Treg) and conventional $\mathrm{T}$ cells enabling direct isolation of alloantigen-reactive natural Foxp $3^{+}$Treg. J Immunol 189: $5985-$ 5994

Shiratori T, Miyatake S, Ohno H, Nakaseko C, Isono K, Bonifacino JS, Saito T. 1997. Tyrosine phosphorylation controls internalization of CTLA-4 by regulating its interaction with clathrin-associated adaptor complex AP-2. Immunity 6: 583-589.

Simpson TR, Quezada SA, Allison JP. 2010. Regulation of CD4 T cell activation and effector function by inducible costimulator (ICOS). Curr Opin Immunol 22: 326-332.

Song J, Salek-Ardakani S, Rogers PR, Cheng M, Van Parijs L, Croft M. 2004. The costimulation-regulated duration of PKB activation controls T cell longevity. Nat Immunol 5: $150-158$.

Song J, So T, Cheng M, Tang X, Croft M. 2005. Sustained survivin expression from OX40 costimulatory signals drives T cell clonal expansion. Immunity 22: 621-631.

Suntharalingam G, Perry MR, Ward S, Brett SJ, CastelloCortes A, Brunner MD, Panoskaltsis N. 2006. Cytokine storm in a phase 1 trial of the anti-CD28 monoclonal antibody TGN1412. N Engl J Med 355: 1018-1028.

Tan JT, Whitmire JK, Ahmed R, Pearson TC, Larsen CP. 1999. 4-1BB ligand, a member of the TNF family, is important for the generation of antiviral CD8 $\mathrm{T}$ cell responses. J Immunol 163: 4859-4868.

Tan JT, Whitmire JK, Murali-Krishna K, Ahmed R, Altman JD, Mittler RS, Sette A, Pearson TC, Larsen CP. 2000. 4 $1 \mathrm{BB}$ costimulation is required for protective anti-viral immunity after peptide vaccination. J Immunol 164: 2320-2325.

Tan AH, Wong SC, Lam KP. 2006. Regulation of mouse inducible costimulator (ICOS) expression by FynNFATc2 and ERK signaling in T cells. J Biol Chem 281: 28666-28678.

Topalian SL, Hodi FS, Brahmer JR, Gettinger SN, Smith DC, McDermott DF, Powderly JD, Carvajal RD, Sosman JA, Atkins MB, et al. 2012. Safety, activity, and immune correlates of anti-PD-1 antibody in cancer. $N$ Engl J Med 366: $2443-2454$.

Tran HM, Nickerson PW, Restifo AC, Ivis-Woodward MA, Patel A, Allen RD, Strom TB, O’Connell PJ. 1997. Distinct mechanisms for the induction and maintenance of allograft tolerance with CTLA4-Fc treatment. J Immunol 159: 2232-2239.

Turka LA, Linsley PS, Lin H, Brady W, Leiden JM, Wei RQ, Gibson ML, Zheng XG, Myrdal S, Gordon D, et al. 1992. T-cell activation by the CD28 ligand B7 is required for cardiac allograft rejection in vivo. Proc Natl Acad Sci 89: 11102-11105.

Ueda H, Howson JM, Esposito L, Heward J, Snook H, Chamberlain G, Rainbow DB, Hunter KM, Smith AN,
Di Genova G, et al. 2003. Association of the T-cell regulatory gene CTLA4 with susceptibility to autoimmune disease. Nature 423: 506-511.

Valk E, Leung R, Kang H, Kaneko K, Rudd CE, Schneider H. 2006. T cell receptor-interacting molecule acts as a chaperone to modulate surface expression of the CTLA- 4 coreceptor. Immunity 25: 807-821.

Van den Eertwegh AJ, Noelle RJ, Roy M, Shepherd DM, Aruffo A, Ledbetter JA, Boersma WJ, Claassen E. 1993. In vivo CD40-gp39 interactions are essential for thymusdependent humoral immunity. I: In vivo expression of CD40 ligand, cytokines, and antibody production delineates sites of cognate T-B cell interactions. J Exp Med 178: $1555-1565$.

Vu MD, Xiao X, Gao W, Degauque N, Chen M, Kroemer A, Killeen N, Ishii N, Li XC. 2007. OX40 costimulation turns off Foxp $3^{+}$Tregs. Blood 110: 2501-2510.

Walker LS, Sansom DM. 2011. The emerging role of CTLA4 as a cell-extrinsic regulator of $\mathrm{T}$ cell responses. Nat Rev Immunol 11: 852-863.

Wang J, Guo Z, Dong Y, Kim O, Hart J, Adams A, Larsen CP, Mittler RS, Newell KA. 2003. Role of 4-1BB in allograft rejection mediated by $\mathrm{CD} 8^{+} \mathrm{T}$ cells. Am J Transplant 3: 543-551.

Wang L, Han R, Hancock WW. 2007. Programmed cell death 1 (PD-1) and its ligand PD-L1 are required for allograft tolerance. Eur J Immunol 37: 2983-2990.

Wang CJ, Kenefeck R, Wardzinski L, Attridge K, Manzotti C, Schmidt EM, Qureshi OS, Sansom DM, Walker LS. 2012. Cutting edge: Cell-extrinsic immune regulation by CTLA-4 expressed on conventional T cells. J Immunol 189: $1118-1122$

Weaver TA, Charafeddine AH, Agarwal A, Turner AP, Russell M, Leopardi FV, Kampen RL, Stempora L, Song M, Larsen CP, et al. 2009. Alefacept promotes co-stimulation blockade based allograft survival in nonhuman primates. Nat Med 15: 746-749.

Wells AD, Li XC, Li Y, Walsh M, Zheng XX, Wu Z, Nuñez G, Tang A, Sayegh M, Hancock WW, Strom TB, Turka LA. 1999. Requirement for $\mathrm{T}$ cell apoptosis in the induction of peripheral transplantation tolerance. Nat Med 5: 1303-1307.

Yang J, Riella LV, Boenisch O, Popoola J, Robles S, Watanabe T, Vanguri V, Yuan X, Guleria I, Turka LA, et al. 2009. Paradoxical functions of B7: CD28 costimulation in a MHC class II-mismatched cardiac transplant model. Am J Transplant 9: 2837-2844.

Ye H, Park YC, Kreishman M, Kieff E, Wu H. 1999. The structural basis for the recognition of diverse receptor sequences by TRAF2. Mol Cell 4: 321-330.

Zhang T, Fresnay S, Welty E, Sangrampurkar N, Rybak E, Zhou H, Cheng XF, Feng Q, Avon C, Laaris A, et al. 2011. Selective CD28 blockade attenuates acute and chronic rejection of murine cardiac allografts in a CTLA-4-dependent manner. Am J Transplant 11: 1599-1609.

Zhang R, Huynh A, Whitcher G, Chang J, Maltzman JS, Turka LA. 2013. An obligate cell-intrinsic function for CD28 in Tregs. J Clin Invest 123: 580-593. 


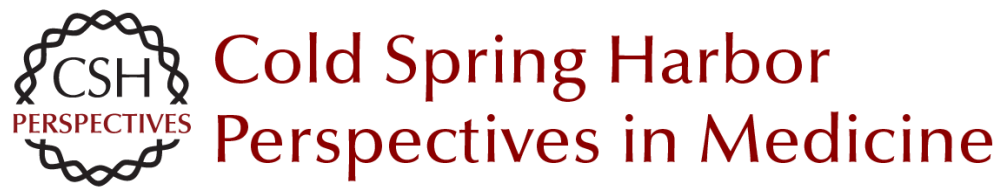

\section{T-Cell Costimulatory Blockade in Organ Transplantation}

Jonathan S. Maltzman and Laurence A. Turka

Cold Spring Harb Perspect Med 2013; doi: 10.1101/cshperspect.a015537

Subject Collection Transplantation

Heart Transplantation: Challenges Facing the Field

Makoto Tonsho, Sebastian Michel, Zain Ahmed, et al.

Bioethics of Organ Transplantation Arthur Caplan

Overview of Clinical Lung Transplantation Jonathan C. Yeung and Shaf Keshavjee

Immunological Challenges and Therapies in

Xenotransplantation Marta Vadori and Emanuele Cozzi

Clinical Aspects: Focusing on Key Unique Organ-Specific Issues of Renal Transplantation Sindhu Chandran and Flavio Vincenti

T-Cell Costimulatory Blockade in Organ

Transplantation Jonathan S. Maltzman and Laurence A. Turka

Regulatory T-Cell Therapy in Transplantation: Moving to the Clinic

Qizhi Tang and Jeffrey A. Bluestone

Opportunistic Infections--Coming to the Limits of Immunosuppression?

Jay A. Fishman
Overview of the Indications and Contraindications

for Liver Transplantation

Stefan Farkas, Christina Hackl and Hans Jürgen Schlitt

Facial and Hand Allotransplantation Bohdan Pomahac, Ryan M. Gobble and Stefan Schneeberger

Induction of Tolerance through Mixed Chimerism David H. Sachs, Tatsuo Kawai and Megan Sykes

Pancreas Transplantation: Solid Organ and Islet Shruti Mittal, Paul Johnson and Peter Friend

Tolerance--Is It Worth It? Erik B. Finger, Terry B. Strom and Arthur J. Matas

Lessons and Limits of Mouse Models Anita S. Chong, Maria-Luisa Alegre, Michelle L. Miller, et al.

Effector Mechanisms of Rejection Aurélie Moreau, Emilie Varey, Ignacio Anegon, et al.

The Innate Immune System and Transplantation Conrad A. Farrar, Jerzy W. Kupiec-Weglinski and Steven H. Sacks

For additional articles in this collection, see http://perspectivesinmedicine.cshlp.org/cgi/collection/ 